\title{
OPEN The impact of second-hand smoke on nitrogen oxides concentrations in a small interior
}

\author{
Markus Braun ${ }^{1 凶}$, Doris Klingelhöfer ${ }^{1}$, Ruth Müller $^{1,2}$ \& David A. Groneberg ${ }^{1}$
}

Nitrogen oxides $\left(\mathrm{NO}_{\mathrm{x}}\right)$, especially nitrogen dioxide $\left(\mathrm{NO}_{2}\right)$, are among the most hazardous forms of air pollution. Tobacco smoke is a main indoor source of $\mathrm{NO}_{x,}$ but little information is available about their concentrations in second-hand smoke (SHS), particularly in small indoors. This study presents data of $\mathrm{NO}_{\mathrm{x}}$ and its main components nitric oxide (NO) and $\mathrm{NO}_{2}$ in $\mathrm{SHS}$ emitted by ten different cigarette brands measured in a closed test chamber with a volume of $2.88 \mathrm{~m}^{3}$, similar to the volume of vehicle cabins. The results show substantial increases in $\mathrm{NO}_{x}$ concentrations when smoking only one cigarette. The $\mathrm{NO}_{2}$ mean concentrations ranged between 105 and $293 \mu \mathrm{g} / \mathrm{m}^{3}$, the $\mathrm{NO}_{2}$ peak concentrations between 126 and $357 \mu \mathrm{g} / \mathrm{m}^{3}$. That means the one-hour mean guideline of $200 \mu \mathrm{g} / \mathrm{m}^{3}$ for $\mathrm{NO}_{2}$ of the World Health Organization was exceeded up to $47 \%$, respectively $79 \%$. The measured $\mathrm{NO}_{2}$ values show positive correlations with the values for tar, nicotine, and carbon monoxide stated by the cigarette manufacturers. This study provides $\mathrm{NO}_{2}$ concentrations in SHS at health hazard levels. These data give rise to the necessity of health authorities' measures to inform about and caution against $\mathrm{NO}_{x}$ exposure by smoking in indoor rooms.

Air pollution is potentially the greatest environmental risk factor for health worldwide. The World Health Organization (WHO) estimates 4.2 million premature deaths per year caused by ambient (outdoor) air pollution and 3.8 million premature deaths caused by indoor air pollution ${ }^{1}$. Since the sulfur dioxide concentrations in the atmosphere decreased in the last decades, the focus is set more and more on particulate matter (PM), ozone, and nitrogen dioxide $\left(\mathrm{NO}_{2}\right)$ as the most hazardous air pollutions ${ }^{2}$.

Nitrogen oxides $\left(\mathrm{NO}_{\mathrm{x}}\right)$, mainly nitric oxide $(\mathrm{NO})$, and, at a lower level, $\mathrm{NO}_{2}$, are gases formed by combustion processes at high temperatures ${ }^{3}$. The main anthropogenic outdoor sources are the combustion of fossil and green fuels in vehicles and power plants. Important indoor sources are oil-, gas-, kerosene-, coal-, and wood-burning ovens, heaters or open fireplaces, and tobacco smoke ${ }^{4}$. In the last years, $\mathrm{NO}_{\mathrm{x}}$ emissions caused by road traffic and diesel vehicles, in particular, came into the focus of the public and policy. Emission limit values of engines were discussed and tightened. The aim was not to exceed the determined limit values of $\mathrm{NO}_{2}$ in ambient air too often, particularly in metropolitan areas. The air quality standards of the European Union for $\mathrm{NO}_{2}$ in ambient air are currently $200 \mu \mathrm{g} / \mathrm{m}^{3}$ ( $1 \mathrm{~h}$ mean, should not exceed more than 18 times each year) and an annual mean of $40 \mu \mathrm{g} / \mathrm{m}^{3}{ }^{5}$. Therewith, they followed the recommendations of the WHO air quality guidelines from $2005^{6}$. As indoor air pollution came more and more into the focus, the WHO published in 2010 guidelines for indoor air quality, whereby the $\mathrm{NO}_{2}$ limit values are consistent with the values for ambient air ${ }^{4}$.

$\mathrm{NO}_{2}$, in particular, is associated with a lot of adverse health effects on several organ systems ${ }^{7}$. Long-term exposure to $\mathrm{NO}_{2}$, besides $\mathrm{PM}$, is an important risk factor for cardiopulmonary mortality ${ }^{8}$. Moreover, the $\mathrm{NO}_{2}$ concentration is positively associated with a variety of harmful effects, the mortality of respiratory and cardiovascular diseases, and lung cancer'.

NO is largely considered a toxic pollutant. The exposure can cause, among others, irritation to the skin, eyes, and respiratory system, but also unconsciousness and methemoglobinemia ${ }^{10}$. Albeit, NO may be hazardous to the health of humans not until relatively high doses ${ }^{11}$. For workplace atmospheres, the U.S. National Institute for Occupational Safety and Health gives an NO exposure limit value ( $8 \mathrm{~h}$ time-weighted-average) of $25 \mathrm{ppm}$ $\left(30 \mathrm{mg} / \mathrm{m}^{3}\right)^{10}$. Under environmental conditions, $\mathrm{NO}$ will be quickly oxidized to $\mathrm{NO}_{2}$ by, e.g., ozone or oxygen. This oxidation process is, however, much slower under indoor conditions ${ }^{4,12}$.

${ }^{1}$ Institute of Occupational Medicine, Social Medicine and Environmental Medicine, Goethe University Frankfurt, Theodor-Stern-Kai 7, 60590 Frankfurt am Main, Germany. ${ }^{2}$ Medical Entomology, Department of Biomedical Sciences, Institute of Tropical Medicine, Nationalestraat 155, 2000 Antwerp, Belgium. ${ }^{\square}$ email: m.braun@ med.uni-frankfurt.de 


\begin{tabular}{|c|c|c|c|c|c|c|}
\hline Brand & Tested cigarettes (n) & Tar (mg) & Nicotine (mg) & Carbon monoxide (mg) & Particulate matter $\mathrm{PM}_{10}\left(\mu \mathrm{g} / \mathrm{m}^{3}\right)$ & Format and attribute \\
\hline $\begin{array}{l}\text { Reference Cigarette 3R4F (RC1, } \\
\text { RC2) }\end{array}$ & $41(\mathrm{RC} 1=21, \mathrm{RC} 2=20)$ & 9.4 & 0.73 & 12 & 1147 & KS Filter \\
\hline Cigarette A Marlboro Gold UAE & 20 & 6 & 0.5 & 7 & 1163 & KS Filter \\
\hline Cigarette B Marlboro Gold GER & 20 & 6 & 0.5 & 7 & 874 & KS Filter \\
\hline Cigarette C Winston Red UAE & 20 & 7 & 0.6 & 7 & 1016 & KS Filter \\
\hline Cigarette D Winston Classic GER & 18 & 10 & 0.8 & 10 & 778 & KS Filter \\
\hline $\begin{array}{l}\text { Cigarette E Parliament Platinum } \\
\text { UAE }\end{array}$ & 24 & 1 & 0.1 & 1 & 1099 & KS Filter \\
\hline $\begin{array}{l}\text { Cigarette F Parliament Night } \\
\text { Blue GER }\end{array}$ & 24 & 10 & 0.8 & 10 & 1071 & 100 s Filter \\
\hline $\begin{array}{l}\text { Cigarette G Pall Mall Menthol } \\
\text { Blast }\end{array}$ & 15 & 10 & 0.8 & 10 & 1103 & KS Filter, mentholated \\
\hline Cigarette H Winston Menthol & 22 & 10 & 0.8 & 10 & 1182 & KS Filter, mentholated \\
\hline Cigarette I Elixyr Menthol & 21 & 10 & 0.8 & 10 & 1186 & KS Filter, mentholated \\
\hline
\end{tabular}

Table 1. Features of the tested cigarette brands. Data on particulate matter $\left(\mathrm{PM}_{10}\right)$ are measured mean concentrations. $\mathrm{PM}_{10}$ data of the reference cigarette $\mathrm{RC} 1$ and the cigarette brands $\mathrm{G}, \mathrm{H}$, and I were adjusted on the $\mathrm{PM}_{10}$ data of the reference cigarette RC2 by statistical data transformation. Information on the reference cigarette is taken from the manufacturer (Kentucky Tobacco Research and Development Center of the University of Kentucky). Information on the cigarettes A to I as specified by the manufacturers. KS King Size, UAE United Arab Emirates, GER Germany.

Several studies investigated indoor air pollution, including $\mathrm{NO}_{\mathrm{x}}$ respectively $\mathrm{NO}_{2}$ concentrations, caused by ovens (primarily gas stoves) or fireplaces for heating or cooking ${ }^{13-19}$. Some studies focused on tobacco smoke reporting a relatively lower influence on $\mathrm{NO}_{\mathrm{x}}$ concentrations by burning tobacco products in normal-sized rooms or houses ${ }^{20-22}$. The impact of second-hand smoke (SHS) on $\mathrm{NO}_{\mathrm{x}}$ burden in very small indoors like smoking cabins, telephone cells, or cabins of vehicles, for example, remains widely unclear. This study presents the results of the $\mathrm{NO}, \mathrm{NO}_{2}$, and $\mathrm{NO}_{\mathrm{x}}\left(\mathrm{NO}+\mathrm{NO}_{2}\right)$ investigations in SHS of ten different cigarette brands with different strengths, additives, and origin in a $2.88 \mathrm{~m}^{3}$ measuring chamber. The measurements were realized as part of the Tobacco Smoke Particles and Indoor Air Quality (ToPIQ) studies ${ }^{23}$ at two PM investigations. The PM-related results of these studies are already described and published ${ }^{24,25}$.

\section{Material and methods}

Tobacco products. The concentrations of $\mathrm{NO}, \mathrm{NO}_{2}$, and $\mathrm{NO}_{\mathrm{x}}$ in $\mathrm{SHS}$ were measured of nine commercial cigarette brands (named cigarette A to I) and the 3R4F reference cigarette (Kentucky Tobacco Research and Development Center, University of Kentucky, USA) ${ }^{26}$. As the measurements took place during two PM investigations, the reference cigarettes (RC) were termed $\mathrm{RC}^{24}$ and $\mathrm{RC} 2^{25}$. The cigarette brands $\mathrm{A}, \mathrm{C}$, and $\mathrm{E}$ were bought at the International Airport of Dubai, United Arab Emirates (UAE), while the brands B, D, and F were from the International Airport of Frankfurt, Germany ${ }^{25}$. Additionally, three mentholated cigarette brands (G, $\mathrm{H}, \mathrm{I})$ were tested, purchased at the central station, Frankfurt, Germany ${ }^{24}$. The brand names of the cigarettes are given in Table 1 . The cigarette brands differ in amounts of tar, nicotine, carbon monoxide (CO), and $\mathrm{PM}_{10}$ (Table 1). Further information on the cigarettes from Germany is available from the tobacco additives database of the Federal Ministry of Food and Agriculture of Germany ${ }^{27}$.

Test chamber. All measurements took place in a test chamber with an internal volume of $2.88 \mathrm{~m}^{3}$. During the experiments, the vents for the supply and exhaust air were closed to minimize air exchange. The test chamber is placed in a laboratory room of the Institute of Occupational Medicine, Social Medicine and Environmental Medicine, Goethe University Frankfurt. The institute is located in an urban area but not near a traffic road. That avoided high $\mathrm{NO}_{\mathrm{x}}$ concentrations in ambient air by road traffic (see baseline evaluation).

Ambient nitrogen oxide monitor $\left(\mathrm{NO}_{\mathbf{x}}\right.$ monitor). To ascertain the $\mathrm{NO}, \mathrm{NO}_{2}$, and $\mathrm{NO}_{\mathrm{x}}\left(\mathrm{NO}+\mathrm{NO}_{2}\right)$ concentrations of SHS, the ambient nitrogen oxide monitor APNA-370 of HORIBA, Ltd. (Kyoto, Japan) was applied ${ }^{28}$. By using a cross-flow modulated semi-decompression chemiluminescence method, $\mathrm{NO}_{2}$ concentrations were internally calculated from those of $\mathrm{NO}$ and $\mathrm{NO}_{\mathrm{x}}$. All measurement values were recorded in the unit ppm (parts per million) every three minutes. The not mixed sample air was collected at a point $40 \mathrm{~cm}$ above the burning tobacco product and $170 \mathrm{~cm}$ above the floor of the test chamber.

Automatic environmental tobacco smoke emitter. SHS was generated in the closed test chamber by an Automatic Environmental Tobacco Smoke Emitter (AETSE), developed and constructed by Schimpf Ing.

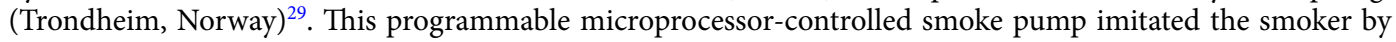
moving a $200 \mathrm{ml}$ glass syringe connected with the mouthpiece of the tobacco product via a polyamide tube. Moving the syringe led to puffing the tobacco product. Two valves controlled the air stream and pressed the 
mainstream smoke after each puff into the closed chamber. Between the puffs, the tobacco product smoldered and produced side-stream smoke. In doing so, no person was exposed to the generated SHS.

Smoking protocol. The number (n) of investigated cigarettes of each brand varied between 15 and 41 (Table 1). According to the ToPIQ studies ${ }^{23-25}$, all cigarettes were smoked following a modified protocol. Puff volume was $40 \mathrm{ml}$, and the flow rate was $13 \mathrm{ml} / \mathrm{s}$. After two ignition puffs, each cigarette was smoked in the combustion phase with seven puffs and a frequency of two puffs $/ \mathrm{min}$. Subsequently, the post-combustion phase followed after the extinguishing of the cigarette. After ten minutes in total, the chamber was ventilated with outdoor air by an industrial radial fan for at least five minutes to clean the air.

Baseline evaluation. As the $\mathrm{NO}_{\mathrm{x}}$ monitor detected data permanently, continuous measuring data of $61 \mathrm{~h}$ between the two measuring campaigns without SHS generation were chosen to determine the baseline values of $\mathrm{NO}, \mathrm{NO}_{2}$, and $\mathrm{NO}_{\mathrm{x}}$.

Data processing. The $\mathrm{NO}_{\mathrm{x}}$ monitor provided every three minutes measuring data. Therefore, in the 10-min combustion and post-combustion phase, three values of $\mathrm{NO}, \mathrm{NO}_{2}$, and $\mathrm{NO}_{\mathrm{x}}$, respectively, per investigated cigarette could be taken into account for the following data processing. The mean concentrations $\left(\mathrm{C}_{\text {mean }}\right)$ of these three measuring values of $\mathrm{NO}, \mathrm{NO}_{2}$, and $\mathrm{NO}_{\mathrm{x}}$ were calculated. Additionally, the highest values of $\mathrm{NO}, \mathrm{NO}_{2}$, and $\mathrm{NO}_{\mathrm{x}}$ were considered as peak values $\left(\mathrm{C}_{\text {peak }}\right)$ for each cigarette. For the statistical analysis, all $\mathrm{C}_{\text {mean }}$ and $\mathrm{C}_{\text {peak }}$ values were tested for outliers (Grubbs' test). Sixteen outliers were detected and subsequently excluded from further statistical tests. All data were normally distributed. To compare the data of all investigated cigarettes, a one-way analysis of variance (ANOVA) including Tukey's multiple comparison test was performed.

The associations of the $\mathrm{C}_{\text {mean }}$ values of $\mathrm{NO}, \mathrm{NO}_{2}$, and $\mathrm{NO}_{\mathrm{x}}$ with concentrations of tar, nicotine, $\mathrm{CO}$, and $\mathrm{PM}_{10}$ were examined by using correlation analysis (Spearman) and linear regression. $\mathrm{PM}_{10}$ is classified by the US Environmental Protection Agency (EPA) as inhalable particles $\leq 10 \mu \mathrm{m}$ and includes the fraction of the fine inhalable particles $\leq 2.5 \mu \mathrm{m}\left(\mathrm{PM}_{2.5}\right)^{30}$. The measured $\mathrm{PM}_{10} \mathrm{C}_{\text {mean }}$ values of RC1 were lower than those of RC2. Therefore, it was necessary to adjust the $\mathrm{PM}_{10}$ data of RC1 and the associated cigarette brands $\mathrm{G}, \mathrm{H}$, and I on the $\mathrm{PM}_{10}$ data of $\mathrm{RC} 2$ by statistical data transformation $\left(\mathrm{Y}=\mathrm{K}^{\star} \mathrm{Y}\right)$ using the factor $\mathrm{K}=1.47$.

Statistical analyses were performed using GraphPad Prism software (version 8 for Windows, GraphPad Software, La Jolla California USA, www.graphpad.com).

Data conversion. For the comparison of the in this study measured values with common used limit values or guidelines, the data of $\mathrm{NO}$ and $\mathrm{NO}_{2}$ were converted in $\mu \mathrm{g} / \mathrm{m}^{3}$ using the formula ${ }^{31}$ :

$$
c\left[\mu \mathrm{g} / \mathrm{m}^{3}\right]=0.0409 \times c[\mathrm{ppb}] \times \mathrm{MW}[\mathrm{g} / \mathrm{mol}]\left(\text { at } 1013.25 \mathrm{mbar} \text { and } 25^{\circ} \mathrm{C}\right)
$$

$c$ concentration, $p p b$ parts per billion, $M W$ molecular weight, $M W N O=30.01 \mathrm{~g} / \mathrm{mol} ; M W N O_{2}=46.01 \mathrm{~g} / \mathrm{mol}$.

As the $\mathrm{NO}_{\mathrm{x}}$ monitor display the data in ppm, all values were multiplied by 1000 to convert to the unit $\mathrm{ppb}$ (parts per billion).

\section{Results}

Table 2 and Fig. 1 present the $\mathrm{NO}, \mathrm{NO}_{2}$, and $\mathrm{NO}_{\mathrm{x}}$ results of $\mathrm{C}_{\text {mean }}$ and $\mathrm{C}_{\text {peak }}$ of all investigated cigarette brands.

Regarding NO, the range of the $C_{\text {mean }}$ values was from 132 to $422 \mathrm{ppb}$ (equal to $162 \mu \mathrm{g} / \mathrm{m}^{3}$ to $518 \mu \mathrm{g} / \mathrm{m}^{3}$ at 1013.25 mbar and $25^{\circ} \mathrm{C}$ ). For $\mathrm{NO}_{2}$, the $\mathrm{C}_{\text {mean }}$ values ranged from 56 to $156 \mathrm{ppb}$ (equal to $105 \mu \mathrm{g} / \mathrm{m}^{3}$ to $293 \mu \mathrm{g} /$ $\mathrm{m}^{3}$ at $1013.25 \mathrm{mbar}$ and $25^{\circ} \mathrm{C}$ ). Looking at the $\mathrm{C}_{\text {mean }}$ data of $\mathrm{NO}_{\mathrm{x}}$, the values ranged from 247 to $499 \mathrm{ppb}$.

The ranges of the ascertained peak values $\left(\mathrm{C}_{\text {peak }}\right)$ were as followed: NO: $207 \mathrm{ppb}$ to $584 \mathrm{ppb}$ (equal to $254 \mu \mathrm{g} /$ $\mathrm{m}^{3}$ to $716 \mu \mathrm{g} / \mathrm{m}^{3}$ at $1013.25 \mathrm{mbar}$ and $25^{\circ} \mathrm{C}$ ). $\mathrm{NO}_{2}$ : $67 \mathrm{ppb}$ to $190 \mathrm{ppb}$ (equal to $126 \mu \mathrm{g} / \mathrm{m}^{3}$ to $357 \mu \mathrm{g} / \mathrm{m}^{3}$ at 1013.25 mbar and $\left.25^{\circ} \mathrm{C}\right) . \mathrm{NO}_{\mathrm{x}}: 349 \mathrm{ppb}$ to $661 \mathrm{ppb}$.

To compare the measured $\mathrm{NO}_{\mathrm{x}}$ values in SHS with the usually $\mathrm{NO}_{\mathrm{x}}$ concentration in indoor air at the study location, we took continuous data of $61 \mathrm{~h}$ where no investigation was done into account recorded between the two measurement campaigns. The mean of the thus collected data resulted in the baselines for $\mathrm{NO}=0.072 \mathrm{ppb}$ (equal to $0.1 \mu \mathrm{g} / \mathrm{m}^{3}$ at $1013.25 \mathrm{mbar}$ and $25^{\circ} \mathrm{C}$ ), $\mathrm{NO}_{2}=5.08 \mathrm{ppb}$ (equal to $9.6 \mu \mathrm{g} / \mathrm{m}^{3}$ at $1013.25 \mathrm{mbar}$ and $25^{\circ} \mathrm{C}$ ) and $\mathrm{NO}_{\mathrm{x}}=5.15 \mathrm{ppb}$.

A detailed overview of associations of the $\mathrm{C}_{\text {mean }}$ values of $\mathrm{NO}, \mathrm{NO}_{2}$, and $\mathrm{NO}_{\mathrm{x}}$ with concentrations of tar, nicotine, $\mathrm{CO}$, and $\mathrm{PM}_{10}$ shows Table 3. Additionally, Fig. 2 presents the correlations between $\mathrm{NO}, \mathrm{NO}_{2}$, and $\mathrm{NO}_{\mathrm{x}}$ and the stated amounts of $\operatorname{tar}(\mathrm{A})$, nicotine (B), CO (C), and the measured values of $\mathrm{PM}_{10}(\mathrm{D})$. The measured NO data are negatively correlated with the concentrations of tar, nicotine, and $\mathrm{CO}$ as specified by the cigarette manufacturers. The concentrations of $\mathrm{NO}_{2}$ correlates positively with the stated values of tar, nicotine, and CO. $\mathrm{NO}_{\mathrm{x}}$ correlated negatively with the concentrations of tar, nicotine, and $\mathrm{CO}$, but in the case of $\mathrm{CO}$ without significance. The measured $\mathrm{PM}_{10}$ values show no correlations with the concentrations of $\mathrm{NO}, \mathrm{NO}_{2}$, and $\mathrm{NO}_{\mathrm{x}}$.

\section{Discussion}

The measured indoor baseline concentration revealed for $\mathrm{NO}_{2}$ a mean value of $9.6 \mu \mathrm{g} / \mathrm{m}^{3}(5.08 \mathrm{ppb})$. That is in line with previous studies on $\mathrm{NO}_{2}$ indoor concentrations ${ }^{20}$. Our findings show remarkable rises of $\mathrm{NO}_{\mathrm{x}}$ in small indoors by the smoke of only one cigarette. Of all ten tested cigarette brands, the measured $\mathrm{C}_{\text {mean }}$ values of five brands exceeded the WHO one-hour mean guideline of $200 \mu \mathrm{g} / \mathrm{m}^{3}$ for $\mathrm{NO}_{2}{ }^{6}$ by $9 \%$ to $47 \%$. The remaining five brands showed between $1.5 \%$ and $47 \%$ lower $\mathrm{NO}_{2}$ values compared to the $\mathrm{WHO}$ guideline. The measured $\mathrm{NO}_{2}$ $\mathrm{C}_{\text {mean }}$ value of all examined cigarettes was $215 \mu \mathrm{g} / \mathrm{m}^{3}(119 \mathrm{ppb})$ and, therefore, exceeded the WHO guideline by 


\begin{tabular}{|c|c|c|c|c|c|c|c|c|c|c|}
\hline & $\begin{array}{l}\mathrm{C}_{\text {mean }} \text { NO } \\
(\mathbf{p p b})\end{array}$ & $\begin{array}{l}C_{\text {mean }} \text { NO ( }(\mu \mathrm{g} / \\
\left.\mathbf{m}^{3}\right)\end{array}$ & $\mathrm{C}_{\text {peak }} \mathrm{NO}(\mathrm{ppb})$ & $\begin{array}{l}C_{\text {peak }} \text { NO ( }(\mu \mathrm{g} / \\
\left.\mathbf{m}^{3}\right)\end{array}$ & $\begin{array}{l}\mathrm{C}_{\text {mean }} \mathrm{NO}_{2} \\
(\mathrm{ppb})\end{array}$ & $\begin{array}{l}\mathrm{C}_{\text {mean }} \mathrm{NO}_{2}(\mu \mathrm{g} / \\
\left.\mathrm{m}^{3}\right)\end{array}$ & $\begin{array}{l}\mathrm{C}_{\text {peak }} \mathrm{NO}_{2} \\
(\mathrm{ppb})\end{array}$ & $\begin{array}{l}\mathrm{C}_{\text {peak }} \mathrm{NO}_{2}(\mu \mathrm{g} / \\
\left.\mathrm{m}^{3}\right)\end{array}$ & $\begin{array}{l}\mathrm{C}_{\text {mean }} \mathrm{NO}_{\mathrm{x}} \\
(\mathrm{ppb})\end{array}$ & $\begin{array}{l}\mathrm{C}_{\text {peak }} \mathrm{NO}_{2} \\
(\mathrm{ppb})\end{array}$ \\
\hline $\mathrm{BL}$ & $0.11(0.15)$ & 0.1 & n/a & $\mathrm{n} / \mathrm{a}$ & $5.08(2.14)$ & 9.6 & $\mathrm{n} / \mathrm{a}$ & $\mathrm{n} / \mathrm{a}$ & $5.15(2.21)$ & $\mathrm{n} / \mathrm{a}$ \\
\hline $\mathrm{RC1}$ & $226(57)$ & 277 & $319(64)$ & 391 & $155(13)$ & 292 & $190(28)$ & 357 & $386(64)$ & $492(66)$ \\
\hline RC2 & $209(29)$ & 256 & $307(48)$ & 377 & $152(16)$ & 286 & $180(21)$ & 339 & $368(26)$ & $476(35)$ \\
\hline A & $394(36)$ & 483 & $563(70)$ & 691 & $80(7)$ & 150 & $94(8)$ & 177 & $475(30)$ & $648(66)$ \\
\hline B & $300(65)$ & 368 & $405(79)$ & 497 & $105(8)$ & 197 & $119(7)$ & 224 & $403(63)$ & $517(76)$ \\
\hline $\mathrm{C}$ & $367(70)$ & 450 & $532(105)$ & 653 & $56(15)$ & 105 & $67(18)$ & 126 & $418(81)$ & $586(119)$ \\
\hline $\mathrm{D}$ & $132(35)$ & 162 & $207(51)$ & 254 & $116(18)$ & 218 & $137(23)$ & 258 & $247(54)$ & $349(90)$ \\
\hline $\mathrm{E}$ & $422(35)$ & 518 & $584(70)$ & 716 & $79(4)$ & 149 & $91(4)$ & 171 & $499(37)$ & $661(77)$ \\
\hline $\mathrm{F}$ & $227(63)$ & 278 & $316(80)$ & 388 & $125(17)$ & 125 & $144(20)$ & 271 & $349(70)$ & $450(82)$ \\
\hline G & $153(42)$ & 188 & $245(72)$ & 301 & $151(24)$ & 284 & $175(26)$ & 329 & $302(44)$ & $402(73)$ \\
\hline $\mathrm{H}$ & $188(25)$ & 231 & $269(46)$ & 330 & $139(11)$ & 261 & $162(11)$ & 305 & $324(32)$ & $416(45)$ \\
\hline I & $164(30)$ & 201 & $232(52)$ & 285 & $156(21)$ & 293 & $184(28)$ & 346 & $317(40)$ & $397(48)$ \\
\hline
\end{tabular}

Table 2. Mean concentrations $\left(\mathrm{C}_{\text {mean }}\right)$ and peak concentrations $\left(\mathrm{C}_{\text {peak }}\right)$ of nitric oxide $(\mathrm{NO})$, nitrogen dioxide $\left(\mathrm{NO}_{2}\right)$, and nitrogen oxides $\left(\mathrm{NO}_{\mathrm{x}}\right)$ of the measured baseline $(\mathrm{BL})$, reference cigarette $3 \mathrm{R} 4 \mathrm{~F}(\mathrm{RC} 1, \mathrm{RC} 2)$, and the cigarette brands A (Marlboro Gold UAE), B (Marlboro Gold GER), C (Winston Red UAE), D (Winston Classic GER), E (Parliament Platinum UAE), F (Parliament Night Blue GER), G (Pall Mall Menthol Blast), H (Winston Menthol), and I (Elixyr Menthol). UAE United Arab Emirates, GER Germany. The given concentrations in the unit $\mu \mathrm{g} / \mathrm{m}^{3}$ were calculated using the formula $c\left(\mu \mathrm{g} / \mathrm{m}^{3}\right)=0.0409 \times c(\mathrm{ppb}) \times M W(\mathrm{~g} / \mathrm{mol})($ at $1013.25 \mathrm{mbar}$ and $25^{\circ} \mathrm{C}, \mathrm{c}=$ concentration, $\mathrm{ppb}=$ parts per billion, $\mathrm{MW}=$ molecular weight, $\mathrm{MW} \mathrm{NO}=30.01 \mathrm{~g} / \mathrm{mol}$, MW $\mathrm{NO}_{2}=46.01 \mathrm{~g} / \mathrm{mol}$ ). Standard deviations are stated in brackets. $\mathrm{n} / \mathrm{a}=$ not available.
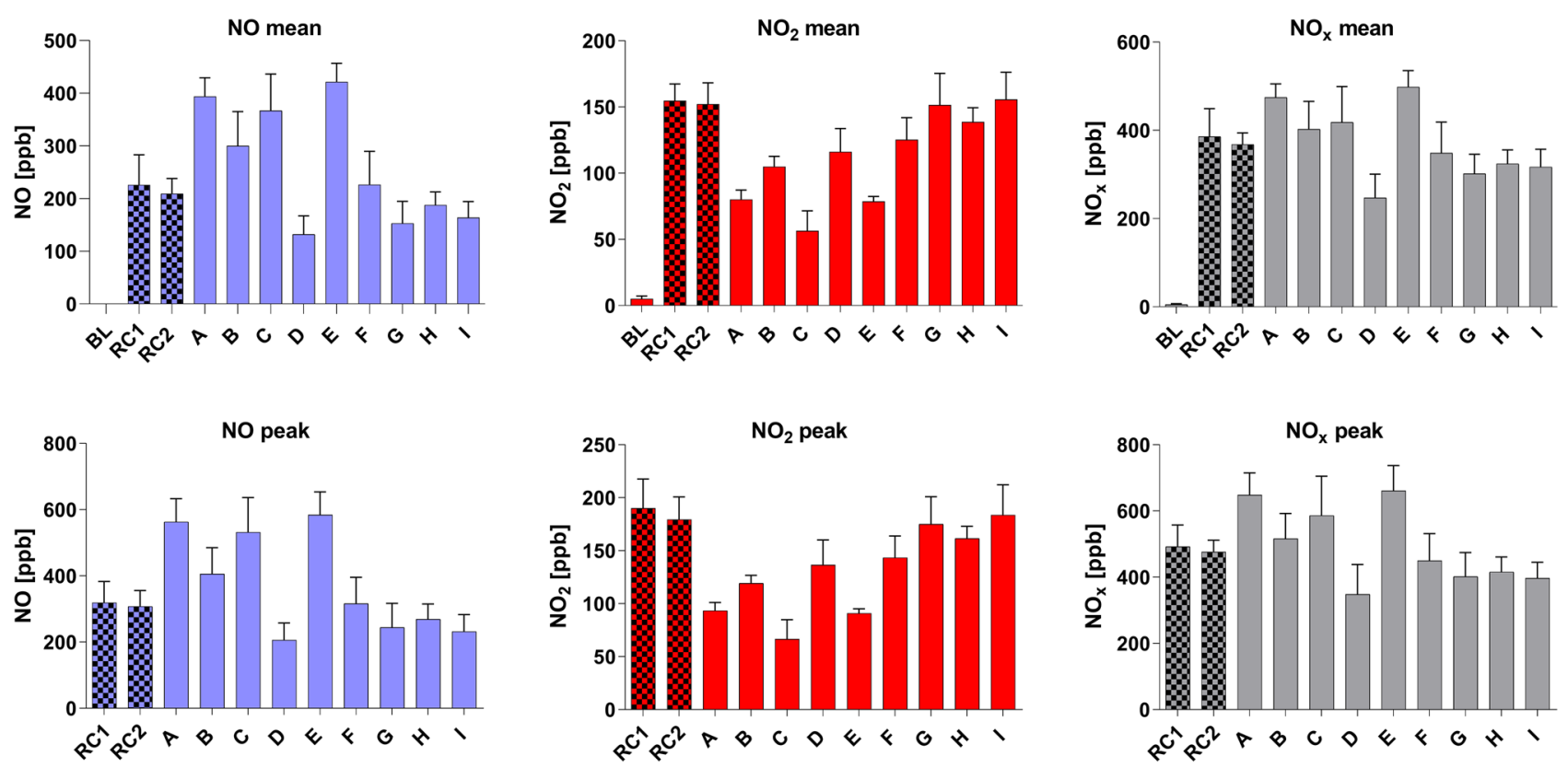

Figure 1. Mean and peak concentrations ( $\mathrm{ppb}$ ) of nitric oxide (NO), nitrogen dioxide $\left(\mathrm{NO}_{2}\right)$, and nitrogen oxides $\left(\mathrm{NO}_{\mathrm{x}}\right)$ of the reference cigarette 3R4F $(\mathrm{RC} 1, \mathrm{RC} 2)$ and the cigarette brands A to I. Baseline (BL) only given at mean concentrations.

$8 \%$. Regarding the detected $\mathrm{C}_{\text {peak }}$ values of $\mathrm{NO}_{2}$, six brands exceeded the WHO guideline even in a range from 12 to $79 \%$. Four brands were $12 \%$ to $37 \%$ below the guideline. The $\mathrm{NO}_{2} \mathrm{C}_{\text {peak }}$ mean value of all cigarettes was $264 \mu \mathrm{g} /$ $\mathrm{m}^{3}(140 \mathrm{ppb})$ and consequently $32 \%$ higher than the WHO guideline value. The WHO state unambiguously "that $\mathrm{NO}_{2}$-at short-term concentrations exceeding $200 \mu \mathrm{g} / \mathrm{m}^{3}$-is a toxic gas with significant health effects" 6 . It should be borne in mind that the WHO annual mean guideline for $\mathrm{NO}_{2}$ is with $40 \mu \mathrm{g} / \mathrm{m}^{3}$ even stricter ${ }^{4}$. There are other guidelines often following the WHO indoor and ambient guidelines for $\mathrm{NO}_{2}$, but some differ ${ }^{32}$. At Health Canada, for example, there is an indoor short-term limit value of $170 \mu \mathrm{g} / \mathrm{m}^{3}$ and a long-term limit value of $20 \mu \mathrm{g} / \mathrm{m}^{3}$ based on toxicological data ${ }^{33}$.

Several former studies dealt with $\mathrm{NO}_{\mathrm{x}}$ emitted by tobacco products in normal-sized indoor rooms. Cyrys et al. ${ }^{20}$ reported $\mathrm{NO}_{2}$ mean concentrations in living rooms in Hamburg and Erfurt (both Germany) of $17 \mu \mathrm{g} / \mathrm{m}^{3}$ 


\begin{tabular}{|c|c|c|c|c|c|c|}
\hline & Spearman $\mathbf{r}$ & $\begin{array}{l}\text { 95\% Confidence } \\
\text { Interval } \\
\end{array}$ & R squared & $P$ value (two-tailed) & $P$ value summery & \begin{tabular}{|l} 
Significant? \\
$(P<0.05)$
\end{tabular} \\
\hline NO versus Tar & -0.87 & -0.9664 to -0.543 & 0.75 & 0.001 & $* *$ & Yes \\
\hline NO versus Nicotine & -0.87 & -0.9664 to -0.543 & 0.75 & 0.001 & $* *$ & Yes \\
\hline $\mathrm{NO}$ versus $\mathrm{CO}$ & -0.67 & -0.9098 to -0.099 & 0.45 & 0.027 & * & Yes \\
\hline NO versus $P M$ & 0.10 & -0.6743 to 0.5429 & 0.11 & 0.760 & ns & No \\
\hline $\mathrm{NO}_{2}$ versus Tar & 0.62 & 0.0163 to 0.8943 & 0.39 & 0.046 & $*$ & Yes \\
\hline $\mathrm{NO}_{2}$ versus Nicotine & 0.62 & 0.0163 to 0.8943 & 0.39 & 0.046 & * & Yes \\
\hline $\mathrm{NO}_{2}$ versus $\mathrm{CO}$ & 0.85 & 0.5075 to 0.9630 & 0.73 & 0.001 & $* *$ & Yes \\
\hline $\mathrm{NO}_{2}$ versus $\mathrm{PM}$ & 0.57 & -0.0666 to 0.8764 & 0.32 & 0.071 & ns & No \\
\hline $\mathrm{NO}_{\mathrm{x}}$ versus Tar & -0.93 & -0.9838 to -0.7521 & 0.87 & $<0.001$ & $* * *$ & Yes \\
\hline $\mathrm{NO}_{\mathrm{x}}$ versus Nicotine & -0.93 & -0.9838 to -0.7521 & 0.87 & $<0.001$ & $* * *$ & Yes \\
\hline $\mathrm{NO}_{\mathrm{x}}$ versus $\mathrm{CO}$ & -0.60 & -0.8879 to 0.0148 & 0.36 & 0.053 & ns & No \\
\hline $\mathrm{NO}_{\mathrm{x}}$ versus $\mathrm{PM}$ & -0.04 & -0.6378 to 0.5866 & $<0.01$ & 0.909 & ns & No \\
\hline
\end{tabular}

Table 3. Spearman correlations of the $\mathrm{C}_{\text {mean }}$ values of $\mathrm{NO}, \mathrm{NO}_{2}$, and $\mathrm{NO}_{\mathrm{x}}$ with concentrations of tar, nicotine, $\mathrm{CO}$ (as specified by the cigarette manufacturers), and $\mathrm{PM}_{10}$. $P$ values show the significance of the correlations. $n s=$ not significant $(P \geq 0.05){ }^{\star}=$ significant $(P=0.01$ to 0.05$) .{ }^{\star *}=$ very significant $(P=0.001$ to $0.01) .{ }^{* *}=$ very significant $(P<0.001)$.
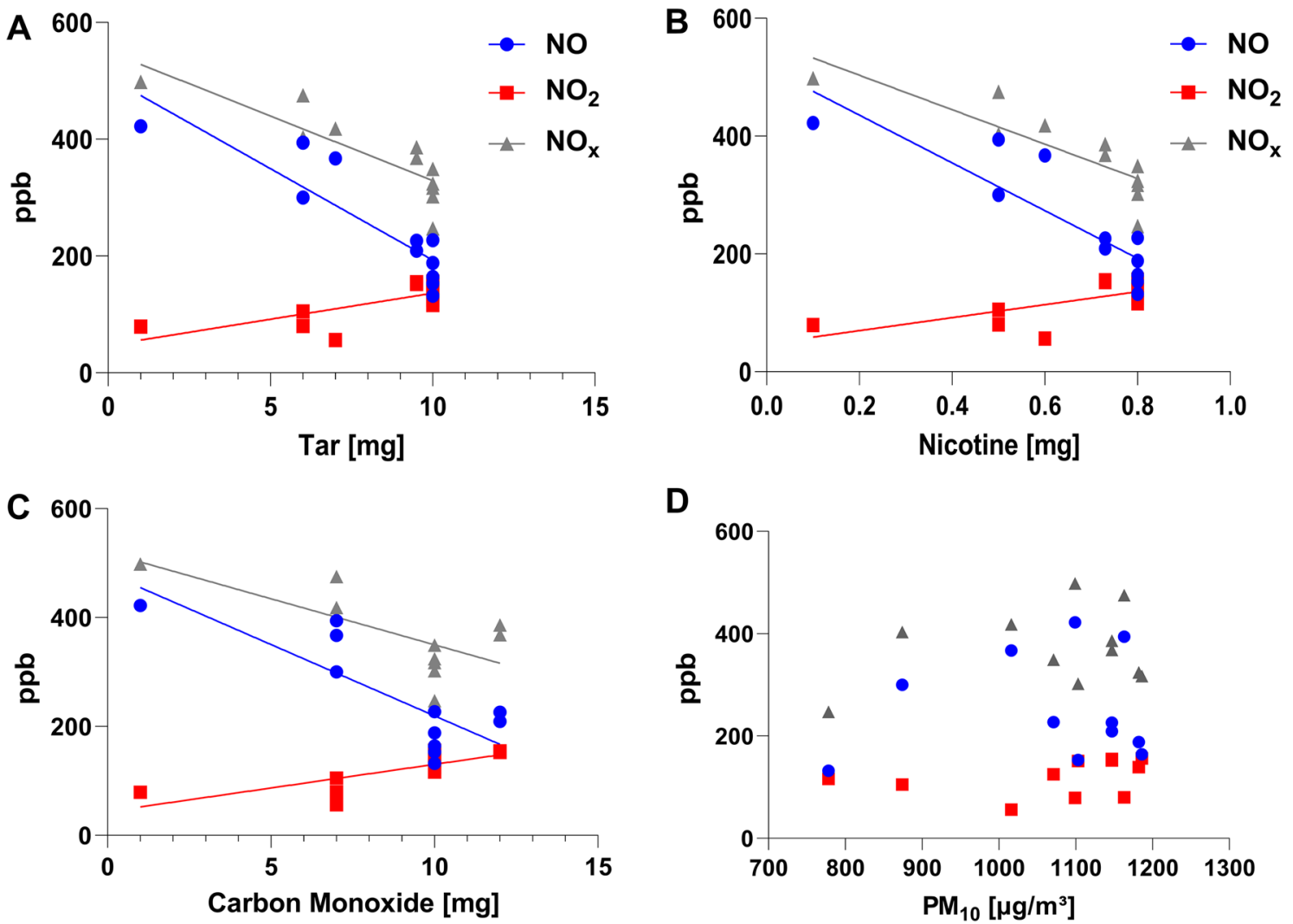

Figure 2. Association between nitric oxide $(\mathrm{NO})$, nitrogen dioxide $\left(\mathrm{NO}_{2}\right)$, and nitrogen oxides $\left(\mathrm{NO}_{\mathrm{x}}\right)$ concentrations and concentrations of $\operatorname{tar}(\mathbf{A})$, nicotine $(\mathbf{B})$, carbon monoxide $(\mathrm{CO})(\mathbf{C})$, and particulate matter $\left(\mathrm{PM}_{10}\right)(\mathrm{D})$. Coefficients of determination $\left(\mathrm{R}^{2}\right)$ of linear regression: NO-tar: 0.779; NO-nicotine: 0.753; NO-CO: 0.684; NO-PM 10 : 0.007; $\mathrm{NO}_{2}$-tar: 0.526; $\mathrm{NO}_{2}$-nicotine: 0.462; $\mathrm{NO}_{2}$-CO: 0.592; $\mathrm{NO}_{2}-\mathrm{PM}_{10}$ : 0.105; $\mathrm{NO}_{\mathrm{x}}$-tar: 0.718; $\mathrm{NO}_{\mathrm{x}}$-nicotine: $0.724 ; \mathrm{NO}_{\mathrm{x}}-\mathrm{CO}: 0.5 ; \mathrm{NO}_{\mathrm{x}}-\mathrm{PM}_{10}$ : 0.079 .

and $15 \mu \mathrm{g} / \mathrm{m}^{3}$, respectively, an increase of $18 \%$ in smokers' homes, and an increase of $41 \%$ in households using gas for cooking, the main indoor source of $\mathrm{NO}_{2}$. Additionally, the authors found that outdoor sources can influence indoor $\mathrm{NO}_{2}$ levels more than indoor sources depending on the location and season of year. However, they differentiated between smoking and non-smoking in the living room (including the use or non-use of gas in the household) and reported on their influence on indoor $\mathrm{NO}_{2}$ levels in general. They did not report on the influence of one single combustion event (burning cigarette or gas cooking, e.g.) and how this can boost $\mathrm{NO}_{2}$ concentration in the indoor air temporarily. Slightly lower $\mathrm{NO}_{2}$ mean concentrations (2-3 weeks averaged) were found 
in Scottish and Irish homes: $12.8 \mu \mathrm{g} / \mathrm{m}^{3}$ (6.82 ppb) in smokers' homes and $16.9 \mu \mathrm{g} / \mathrm{m}^{3}$ (9.01 ppb) in households where gas was used for cooking ${ }^{22}$. In a $20 \mathrm{~m}^{2}$ room with a volume of $57 \mathrm{~m}^{3}$, water pipes were smoked in four-hour sessions, and $\mathrm{NO}$ and $\mathrm{NO}_{2}$ concentrations were measured ${ }^{21}$. The authors reported for the smoking sessions a $\mathrm{NO}$ mean concentration of $100 \mathrm{ppb}$ and $\mathrm{NO}_{2}$ mean concentration of $60 \mathrm{ppb}$, meaning $123 \mu \mathrm{g} / \mathrm{m}^{3}$ and $113 \mu \mathrm{g} / \mathrm{m}^{3}$, respectively. That indicates that smoking significantly increases $\mathrm{NO}_{\mathrm{x}}$ concentrations also in normal-sized indoor rooms. Our study found remarkable mean values (up to $518 \mu \mathrm{g} / \mathrm{m}^{3}$ for $\mathrm{NO}$ and $293 \mu \mathrm{g} / \mathrm{m}^{3}$ for $\mathrm{NO}_{2}$ ) and peak values (up to $716 \mu \mathrm{g} / \mathrm{m}^{3}$ for $\mathrm{NO}$ and $357 \mu \mathrm{g} / \mathrm{m}^{3}$ for $\mathrm{NO}_{2}$ ) caused by smoking of only one cigarette. Admittedly, the measuring chamber with an indoor volume of $2.88 \mathrm{~m}^{3}$ corresponds more to vehicle indoor volumes than indoor volumes of living rooms. However, it can be assumed that chain-smoking or simultaneously smoking of several cigarettes (by several smokers) will increase $\mathrm{NO}_{\mathrm{x}}$ concentrations also in larger rooms in a similar way. Therefore, this should be in focus for future studies.

The present findings show statistically significant correlations between the strength of a cigarette brand (amount of tar, nicotine, and $\mathrm{CO}$ as stated by the manufacturers) and the measured data of $\mathrm{NO}, \mathrm{NO}_{2}$, and $\mathrm{NO}_{\mathrm{x}}$. Interestingly, the lower the tar, nicotine, and $\mathrm{CO}$ values, the higher were the measured $\mathrm{NO}$ and $\mathrm{NO}_{\mathrm{x}}$ levels, while the measured $\mathrm{NO}_{2}$ levels correlated positively with the cigarette strength but with lower significance. The higher the combustion temperature, the more $\mathrm{NO}_{\mathrm{x}}$ will be generated ${ }^{4}$. Also, the content of bound nitrogen in the tobacco product in the form of nitrate or nitrosamine compounds, e.g., could influence the $\mathrm{NO}_{\mathrm{x}}$ amount in tobacco smoke $^{34,35}$. Possibly, "lighter" cigarettes burn at smoking with higher combustion temperatures or contain more bound nitrogen. Further investigations on more numerous cigarette brands with various strengths should also examine the burning temperature and the nitrogen amount of the tobacco product. It was reported that NO and $\mathrm{NO}_{\mathrm{x}}$ concentrations in the mainstream smoke of cigarettes correlated positively with their strength ${ }^{36}$, whereby generation of mainstream smoke took place in a smoking machine following ISO machine-smoking conditions with an as short as possible distance to the $\mathrm{NO}_{\mathrm{x}}$ analyzer ${ }^{37}$. This set-up is rather comparable to a smokers' $\mathrm{NO}_{\mathrm{x}}$ exposure inhaling mainstream smoke. In opposite to this, we simulated the situation of a person exposed to SHS near a burning cigarette. Other studies focusing on $\mathrm{NO}_{\mathrm{x}}$ in mainstream smoke detected mainly NO but almost no $\mathrm{NO}_{2}{ }^{38-40}$. Among others, it was assumed that the reducing conditions near the glowing zone of the cigarette favor the formation of $\mathrm{NO}$ as the lower oxide of nitrogen or that reactive volatile organic compounds (VOCs) in the tobacco smoke react with $\mathrm{NO}_{2}{ }^{38}$. Some $\mathrm{NO}_{2}$ was detected in the mainstream smoke from the initial puff, but not from the following puffs, while $\mathrm{NO}_{2}$ was detected continuously in the side-stream smoke ${ }^{40}$. Only when using a Cambridge filter pad between the cigarette and the analyzer $\mathrm{NO}_{2}$ was observed for each puff. The on the pad sampled smoke of the previous puffs could have interacted with $\mathrm{NO}$ in the smoke forming $\mathrm{NO}_{2}$. As the pad also acted as a barrier between the cigarette and the analyzer, the smoke could age, and, consequently, $\mathrm{NO}_{2}$ values could increase $\mathrm{e}^{40}$. That indicates that the more toxic $\mathrm{NO}_{2}$ is mainly detectable in side-stream smoke and aged smoke but less in mainstream smoke and during a prompt measurement. Since SHS is mainly composed of side-stream smoke $(85 \%)^{41}$, the detection of $\mathrm{NO}_{2}$ in SHS is plausible. In addition, the smoke generated in this study had time to age.

A strength of the present study was that the used measuring set-up in the test chamber allowed to create and investigate SHS in a reproducible way without the exposition of any person to tobacco smoke. A methodological limitation was the low frequency of only three measurements per cigarette by the $\mathrm{NO}_{\mathrm{x}}$ monitor used. Therefore, the real peak values of $\mathrm{NO}, \mathrm{NO}_{2}$, and $\mathrm{NO}_{\mathrm{x}}$ could not be detected in all investigated cigarettes. That resulted possibly in slightly too low $\mathrm{C}_{\text {mean }}$ and $\mathrm{C}_{\text {peak }}$ measurement values.

\section{Conclusion}

In the last years, the discussion about $\mathrm{NO}_{\mathrm{x}}$ and especially $\mathrm{NO}_{2}$ generated by diesel vehicles in urban areas has made massive waves. To name is the so-called Dieselgate scandal commenced in September $2015^{42}$. The focus was set on ambient $\mathrm{NO}_{\mathrm{x}}$ formation, certainly, influencing also indoor burden by $\mathrm{NO}_{\mathrm{x}}$. But, smoking is a not neglecting source of $\mathrm{NO}_{\mathrm{x}}$ in indoor rooms. The present study provides $\mathrm{NO}_{2}$ concentrations in $\mathrm{SHS}$ generated by smoking cigarettes in small indoors at levels known to be a health hazard. Keeping in mind that the used test chamber $\left(2.88 \mathrm{~m}^{3}\right)$ has a similar volume to vehicle cabins ${ }^{43}$, smoking in cars can lead to a hazardous increase of $\mathrm{NO}_{2}$ concentration. This risk multiplies accordingly if more than one cigarette is smoked (e.g., chain smoking), there is more than one smoker in the car, or the car is driven with closed windows without sufficient ventilation. Therefore, health authorities' measures are useful and required to inform about and caution against $\mathrm{NO}_{\mathrm{x}}$ exposure by smoking in cars and other indoor rooms.

\section{Data availability}

Datasets of this study are available from the corresponding author upon request.

Received: 10 February 2021; Accepted: 20 May 2021

Published online: 03 June 2021

\section{References}

1. WHO. World Health Organization. Air pollution, accessed 27 April 2020. http://origin.who.int/airpollution/en/ (2020).

2. Brunekreef, B. \& Holgate, S. T. Air pollution and health. Lancet 360, 1233-1242. https://doi.org/10.1016/S0140-6736(02)11274-8 (2002).

3. Glarborg, P., Miller, J. A., Ruscic, B. \& Klippenstein, S. J. Modeling nitrogen chemistry in combustion. Prog. Energy Combust. 67, 31-68. https://doi.org/10.1016/j.pecs.2018.01.002 (2018).

4. Jarvis, D. .J., Adamkiewicz, G., Heroux, M. E., Rapp, R. \& Kelly, F. J. Nitrogen dioxide. in WHO Guidelines for Indoor Air Quality: Selected Pollutants WHO Guidelines Approved by the Guidelines Review Committee (2010). 
5. EU. European Union. European Commission. Environment. Air Quality Standards, accessed 07 May 2020. https://ec.europa.eu/ environment/air/quality/standards.htm (2019).

6. WHO. World Health Organization. Air quality guidelines for particulate matter,ozone, nitrogendioxide and sulfur dioxide, accessed 07 May 2020. https://www.who.int/phe/health_topics/outdoorair/outdoorair_aqg/en/ (2005).

7. Schraufnagel, D. E. et al. Air pollution and noncommunicable diseases: a review by the forum of international respiratory societies' environmental committee, part 2: air pollution and organ systems. Chest 155, 417-426. https://doi.org/10.1016/j.chest.2018.10. 041 (2019).

8. Cesaroni, G. et al. Long-term exposure to urban air pollution and mortality in a cohort of more than a million adults in Rome. Environ. Health Perspect. 121, 324-331. https://doi.org/10.1289/ehp.1205862 (2013).

9. Atkinson, R. W., Butland, B. K., Anderson, H. R. \& Maynard, R. L. Long-term concentrations of nitrogen dioxide and mortality: a meta-analysis of cohort studies. Epidemiology 29, 460-472. https://doi.org/10.1097/EDE.0000000000000847 (2018).

10. CDC. Centers for Disease Control and Prevention. U.S. Department of Health \& Human Services. The National Institute for Occupational Safety and Health (NIOSH, accessed 09 June 2020). https://www.cdc.gov/niosh/npg/npgd0448.html. (2019).

11. Miller, O. I., Celermajer, D. S., Deanfield, J. E. \& Macrae, D. J. Guidelines for the safe administration of inhaled nitric oxide. Arch. Dis. Child Fetal. Neonatal. Ed. 70, F47-49. https://doi.org/10.1136/fn.70.1.f47 (1994).

12. Arashidani, K. et al. Indoor pollution from heating. Ind. Health 34, 205-215. https://doi.org/10.2486/indhealth.34.205 (1996).

13. Dennekamp, M. et al. Ultrafine particles and nitrogen oxides generated by gas and electric cooking. Occup. Environ. Med. 58, 511-516. https://doi.org/10.1136/oem.58.8.511 (2001).

14. Raw, G. J., Coward, S. K., Brown, V. M. \& Crump, D. R. Exposure to air pollutants in English homes. J. Expo. Anal. Environ. Epidemiol. 14(Suppl 1), S85-94. https://doi.org/10.1038/sj.jea.7500363 (2004).

15. Willers, S. M. et al. Gas cooking, kitchen ventilation, and exposure to combustion products. Indoor Air 16, 65-73. https://doi.org/ 10.1111/j.1600-0668.2005.00404.x (2006).

16. Gilbert, N. L. et al. Housing characteristics and indoor concentrations of nitrogen dioxide and formaldehyde in Quebec City Canada. Environ. Res. 102, 1-8. https://doi.org/10.1016/j.envres.2006.02.007 (2006)

17. Baxter, L. K., Clougherty, J. E., Laden, F. \& Levy, J. I. Predictors of concentrations of nitrogen dioxide, fine particulate matter, and particle constituents inside of lower socioeconomic status urban homes. J. Expo. Sci. Environ. Epidemiol. 17, 433-444. https://doi. org/10.1038/sj.jes.7500532 (2007).

18. Gillespie-Bennett, J. et al. Sources of nitrogen dioxide (NO2) in New Zealand homes: findings from a community randomized controlled trial of heater substitutions. Indoor Air 18, 521-528. https://doi.org/10.1111/j.1600-0668.2008.00554.x (2008).

19. Kephart, J. L. et al. Nitrogen dioxide exposures from biomass cookstoves in the Peruvian Andes. Indoor Air https://doi.org/10. 1111/ina.12653 (2020).

20. Cyrys, J., Heinrich, J., Richter, K., Wolke, G. \& Wichmann, H. E. Sources and concentrations of indoor nitrogen dioxide in Hamburg (west Germany) and Erfurt (east Germany). Sci. Total Environ. 250, 51-62. https://doi.org/10.1016/s0048-9697(00)00361-2 (2000).

21. Fromme, H. et al. Indoor air contamination during a waterpipe (narghile) smoking session. Food Chem. Toxicol. 47, 1636-1641. https://doi.org/10.1016/j.fct.2009.04.017 (2009).

22. Semple, S. et al. Contribution of solid fuel, gas combustion, or tobacco smoke to indoor air pollutant concentrations in Irish and Scottish homes. Indoor Air 22, 212-223. https://doi.org/10.1111/j.1600-0668.2011.00755.x (2012).

23. Gerber, A., Hofen-Hohloch, A. V., Schulze, J. \& Groneberg, D. A. Tobacco smoke particles and indoor air quality (ToPIQ-II): a modified study protocol and first results. J. Occup. Med. Toxicol. 10, 5. https://doi.org/10.1186/s12995-015-0047-8 (2015).

24. Gerharz, J. et al. Particulate matter emissions of different brands of mentholated cigarettes. J. Air Waste Manag. Assoc. 68, 608-615. https://doi.org/10.1080/10962247.2017.1417184 (2018).

25. Braun, M., Al-Qaysi, R., Klingelhofer, D., Muller, R. \& Groneberg, D. A. High particulate matter burden of cigarettes from the united arab emirates and germany: Are there country-specific differences?. Int. J. Environ. Res. Public Health https://doi.org/10. 3390/ijerph17072415 (2020).

26. UK. University of Kentucky, Kentucky Tobacco Research and Development Center, 3R4F Preliminary Analysis, accessed 11 May 2020. https://ctrp.uky.edu/assets/pdf/webdocs/3R4F\%20Preliminary\%20Analysis.pdf (2018).

27. BMEL. Bundesministerium für Ernährung und Landwirtschaft. Tabakzusatzstoffe, accessed 11 May 2020. https://service.bmel. de/tabakerzeugnisse/index2.php?site_key=153 (2011).

28. HORIBA. Ambient NOx monitor APNA-370 Operation Manual, accessed 13 May 2020. https://www.horiba.com/fileadmin/uploa ds/Process-Environmental/Documents/Manuals_US/Ambient/APNA-370_Operation_manual_e.pdf (2009).

29. Schimpf-Ing. Electronic Development, accessed 15 May 2020. http://www.schimpf-ing.no/index_e.html (2020).

30. EPA. United States Environmental Protection Agency. Particulate Matter (PM) Pollution, accessed 06. May 2021. https://www. epa.gov/pm-pollution (2020).

31. Boguski, T. K. KSU. Kansas State University. CHSR. Center for Hazardous Substance Research. Environmental Science and Technology Briefs for Citizens, accessed 26 May 2020. https://www.teesing.com/files/source/understanding-units-of-measurement. pdf (2006).

32. Salonen, H., Salthammer, T. \& Morawska, L. Human exposure to NO2 in school and office indoor environments. Environ. Int. 130, 104887. https://doi.org/10.1016/j.envint.2019.05.081 (2019).

33. Health. Canada. Residential indoor air quality guideline: nitrogen dioxide, accessed 02 July 2020. https://www.canada.ca/en/ health-canada/services/publications/healthy-living/residential-indoor-air-quality-guideline-nitrogen-dioxide.html (2015).

34. Adams, J. D., Lee, S. J. \& Hoffmann, D. Carcinogenic agents in cigarette smoke and the influence of nitrate on their formation. Carcinogenesis 5, 221-223. https://doi.org/10.1093/carcin/5.2.221 (1984).

35. Lam, E., Kelley, E., Martin, S. \& Buettner, G. Tobacco xenobiotics release nitric oxide. Tob. Induc. Dis. 1, 207-211. https://doi.org/ 10.1186/1617-9625-1-3-207 (2003).

36. Counts, M. E., Hsu, F. S., Laffoon, S. W., Dwyer, R. W. \& Cox, R. H. Mainstream smoke constituent yields and predicting relationships from a worldwide market sample of cigarette brands: ISO smoking conditions. Regul. Toxicol. Pharmacol. 39, 111-134. https://doi.org/10.1016/j.yrtph.2003.12.005 (2004).

37. ISO. Standard 3308 , fourth ed., International Organization for Standardization. Routine analytical cigarette-smoking machinedefinitions and standard conditions. (2000).

38. Norman, V. \& Keith, C. H. Nitrogen oxides in tobacco smoke. Nature 205, 915-920. https://doi.org/10.1038/205915b0 (1965).

39. Jenkins, R. A. \& Gill, B. E. Determination of oxides of nitrogen (NOx) in cigarette smoke by chemiluminescent analysis. Anal. Chem. 52, 925-928. https://doi.org/10.1021/ac50056a035 (1980).

40. Shorter, J. H. et al. Measurement of nitrogen dioxide in cigarette smoke using quantum cascade tunable infrared laser differential absorption spectroscopy (TILDAS). Spectrochim. Acta A Mol. Biomol. Spectrosc. 63, 994-1001. https://doi.org/10.1016/j.saa.2005. 11.005 (2006).

41. Raupach, T., Radon, K., Nowak, D. \& Andreas, S. Passive smoking-health consequences and effects of exposure prevention. Pneumologie 62, 44-50. https://doi.org/10.1055/s-2007-980154 (2008).

42. Grange, S. K., Farren, N. J., Vaughan, A. R., Davison, J. \& Carslaw, D. C. Post-dieselgate: evidence of NOx emission reductions using on-road remote sensing. Environ. Sci. Technol. Lett. 7, 382-387. https://doi.org/10.1021/acs.estlett.0c00188 (2020). 
43. EPA. Environmental Protection Agency. Department of Energy. Fuel Economy Guide, accessed 27 May 2020. https://www.fuele conomy.gov/feg/pdfs/guides/FEG2018.pdf (2018).

\section{Acknowledgements}

The authors thank Julia Gerharz and Rawya Al-Qaysi for performing the particulate matter experiments on which this study base.

\section{Author contributions}

M.B., D.K., R.M., and D.A.G. contributed significantly to the conception and design of the study. Moreover, they prepared the experiments, which were performed by M.B. M.B. analyzed the data. The manuscript was written by M.B. and critically reviewed by all authors. All authors have participated sufficiently in the work to take public responsibility for appropriate portions of the content. All authors agreed to be accountable for all aspects of the work in ensuring that questions related to the accuracy or integrity of any part of the work are appropriately investigated and resolved. All authors have read and approved the final manuscript.

\section{Funding}

Open Access funding enabled and organized by Projekt DEAL. This research received no specific grant from any funding agency in the public, commercial, or not-for-profit sectors.

\section{Competing interests}

The authors declare no competing interests.

\section{Additional information}

Correspondence and requests for materials should be addressed to M.B.

Reprints and permissions information is available at www.nature.com/reprints.

Publisher's note Springer Nature remains neutral with regard to jurisdictional claims in published maps and institutional affiliations.

Open Access This article is licensed under a Creative Commons Attribution 4.0 International License, which permits use, sharing, adaptation, distribution and reproduction in any medium or format, as long as you give appropriate credit to the original author(s) and the source, provide a link to the Creative Commons licence, and indicate if changes were made. The images or other third party material in this article are included in the article's Creative Commons licence, unless indicated otherwise in a credit line to the material. If material is not included in the article's Creative Commons licence and your intended use is not permitted by statutory regulation or exceeds the permitted use, you will need to obtain permission directly from the copyright holder. To view a copy of this licence, visit http://creativecommons.org/licenses/by/4.0/.

(C) The Author(s) 2021 